\title{
Ectoparasitism by a dinoflagellate (Dinoflagellata: Oodinidae) on 5 ctenophores (Ctenophora) and a hydromedusa (Cnidaria)
}

\author{
Claudia E. Mills ${ }^{1}$, Norman McLean ${ }^{1,2}$ \\ ${ }^{1}$ Friday Harbor Laboratories, University of Washington, 620 University Road, Friday Harbor, Washington 98250, USA \\ ${ }^{2}$ Department of Biology, San Diego State University, San Diego, California 92182-0057, USA
}

\begin{abstract}
Oodinium sp., an ectoparasitic oodinid dinoflagellate that closely resembles Oodinium jordani McLean \& Nielsen, 1989 described from Sagitta elegans Verrill, 1873 (Phylum Chaetognatha), has been seen to parasitize Beroe abyssicola Mortensen, 1927, Bolinopsis ?infundibulum (O. F. Müller, 1776), Euplokamis dunlapae Mills, 1987, Dryodora glandiformis (Mertens, 1833), and Pleurobrachia bachei A. Agassiz, 1860, which represent 3 orders of the phylum Ctenophora, and the hydromedusa Euphysa sp. (phylum Cnidaria) in marine waters of the San Juan Archipelago, Washington State, USA. Up to several hundred trophozoites may be found on a single ctenophore, although most ctenophore hosts carry less than 50; the hydromedusa never carried more than 4 . The parasites occurred on their ctenophore and medusan hosts from late October through early April, and not in the warmer months These are the first reported instances of parasitism by a dinoflagellate on the Ctenophora, and by an Oodinium on the Cnidaria.
\end{abstract}

\section{INTRODUCTION}

A recent study (McLean \& Nielsen 1989) described Oodinium jordani, a new species of oodinid dinoflagellate ectoparasitic on a member of the phylum Chaetognatha from northwest Washington State, USA. The genus Oodinium was previously known only from European waters. We have observed an oodinid similar to O. jordani ectoparasitic on the ctenophores Beroe abyssicola (order Beroida), Bolinopsis ?infundibulum (order Lobata), Euplokamis dunlapae (order Cydippida), Dryodora glandiformis (order Cydippida), and Pleurobrachia bachei (order Cydippida) and on the jellyfish Euphysa sp. (phylum Cnidaria, order Hydrozoa) in the geographical region from which $O$. jordani was collected. A number of other species of ctenophores, medusae, and siphonophores were also examined, but did not carry Oodinium trophozoites.

\section{MATERIALS AND METHODS}

Specimens of Beroe abyssicola Mortensen, 1927 , Bolinopsis ?infundibulum (O. F. Müller, 1776), Euplo- kamis dunlapae Mills, 1987, Dryodora glandiformis (Mertens, 1833), Pleurobrachia bachei A. Agassiz, 1860, Euphysa sp., and (for comparison) Sagitta elegans Verrill, 1873, were hand-collected in beakers from the floating docks of the Friday Harbor Laboratories, San Juan Archipelago, Washington, USA (48 $32^{\prime} \mathrm{N}$ lat., $123^{\circ} 00^{\prime} \mathrm{W}$. long.), and maintained in circulating seawater (ca $10^{\circ} \mathrm{C}$ ) at the Laboratories. Initial observations of attached trophozoites were made on living specimens; growth measurements of attached trophozoites were made using a dissecting microscope. The seasonality of the attached trophozoites was determined by collecting year-round from November 1989 through November 1990.

For light microscopy, parasites were fixed in $3 \%$ glutaraldehyde (Ladd) in $0.1 \mathrm{M}$ phosphate buffer ( $\mathrm{pH}$ 7.3) with $0.35 \mathrm{M}$ sucrose $\left(20^{\circ} \mathrm{C}, 1 \mathrm{~h}\right)$, rinsed briefly in buffer with sucrose, postfixed on ice in $1 \%$ osmium tetroxide in $0.1 \mathrm{M}$ phosphate buffer ( $\mathrm{pH} 7.3$ ) with 0.35 $M$ sucrose $(1 \mathrm{~h})$, dehydrated in an acetone series and embedded in Spurr's medium (Ladd). Sections $1 \mu \mathrm{m}$ thick were stained in $1 \%$ methylene blue in $1 \%$ borax and $1 \%$ azure II, and examined in a light microscope. 


\section{RESULTS}

\section{Morphology}

The trophozoites of the oodinid that we collected on ctenophores (Figs. $1 \& 2$ ) and on the hydromedusa were oval, with lengths of 100 to $350 \mu \mathrm{m}$, and widths of 35 to $250 \mathrm{~mm}$, the larger specimens becoming increasingly globose. These parasites ranged in color from white to yellow to yellowish brown in sunlight. The large, oval nucleus was situated centrally; beneath it, the peduncular bulb was divided into a proximal and a distal portion by a transverse constriction (Fig. 3). A prominent dense ring (Fig. 3) marked the boundary between the peduncular bulb and the proximal region of the longitudinally ndged attachment organelle or peduncle, which was always transparent and colorless, and which penetrated beneath the epidermal cells of the host. Our qualitative light microscopic observations indicated that the ridges on some of the ctenophoral parasites rose less abruptly from the peduncular surface, and did not extend so far from the surface, as did the ridges of Oodinium jordani; however a nearly complete continuum from broad low ridges to abrupt tall ridges was seen in sections of the ctenophore-borne oodinid. In other aspects, the morphology of Oodinium sp. trophozoites reported here was indistinguishable from O. jordani (see McLean \& Nielsen 1989).

\section{Ecology}

The trophozoites of the parasite were attached to the epithelium of the hosts. On all species of ctenophore, nearly all of the parasites were attached along the length of the comb rows (Fig. 1) and, in Beroe abyssicola, also on the aboral papillae. A small percentage of trophozoites were attached on the ciliated grooves leading to the statocyst, on the body surface between comb rows, or, on Bolinopsis ?infundibulum, along the subpharyngeal canals that continue up the lobes beyond the comb rows and then snake around the inside surface of the lobes. Along the comb rows of all ctenophores, most trophozoites were attached to the epithelium within $25 \mu \mathrm{m}$ of the sides of the comb rows (Figs. 1 \& 2), but some had attached within the comb rows between adjacent comb plates. Parasites along the comb rows were agitated vigorously by the beating of the locomotory cilia. In most ctenophores, entire comb rows and the aboral papillae were withdrawn upon stimulation with a probe, and covered by adjacent tissue. Such a protective posture removed the
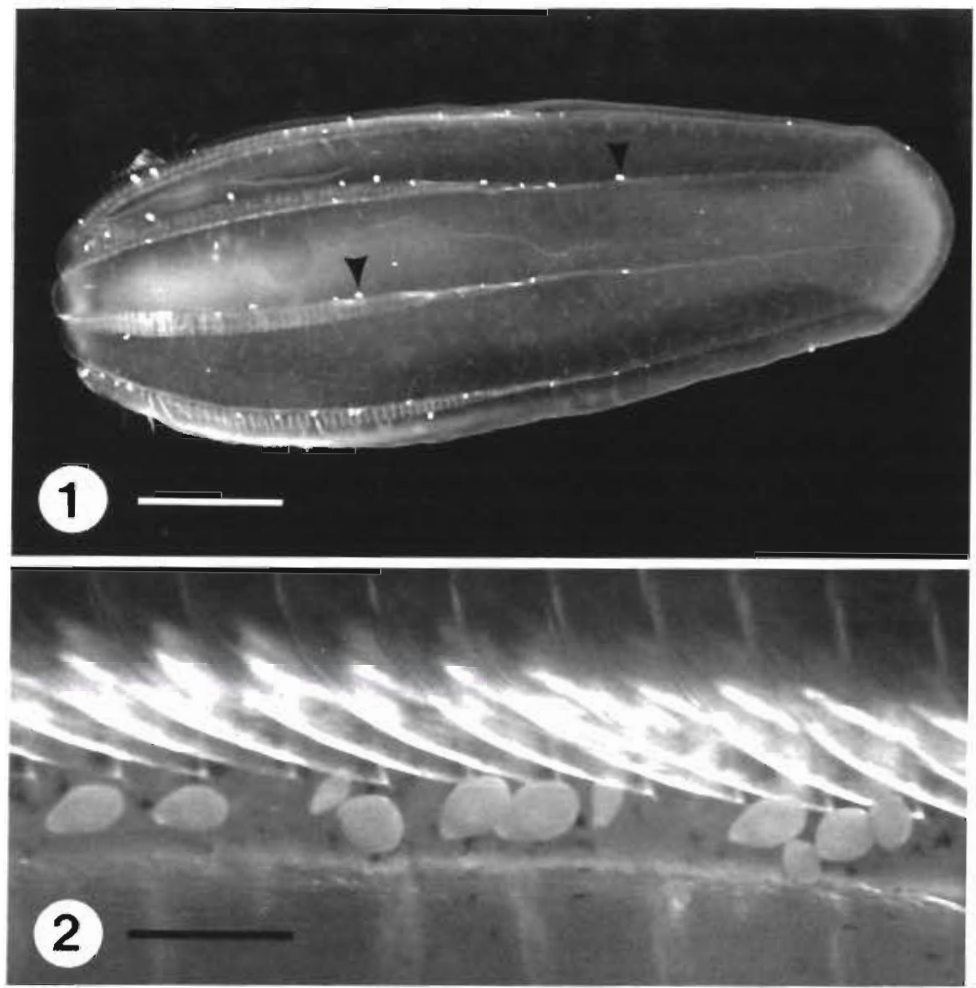

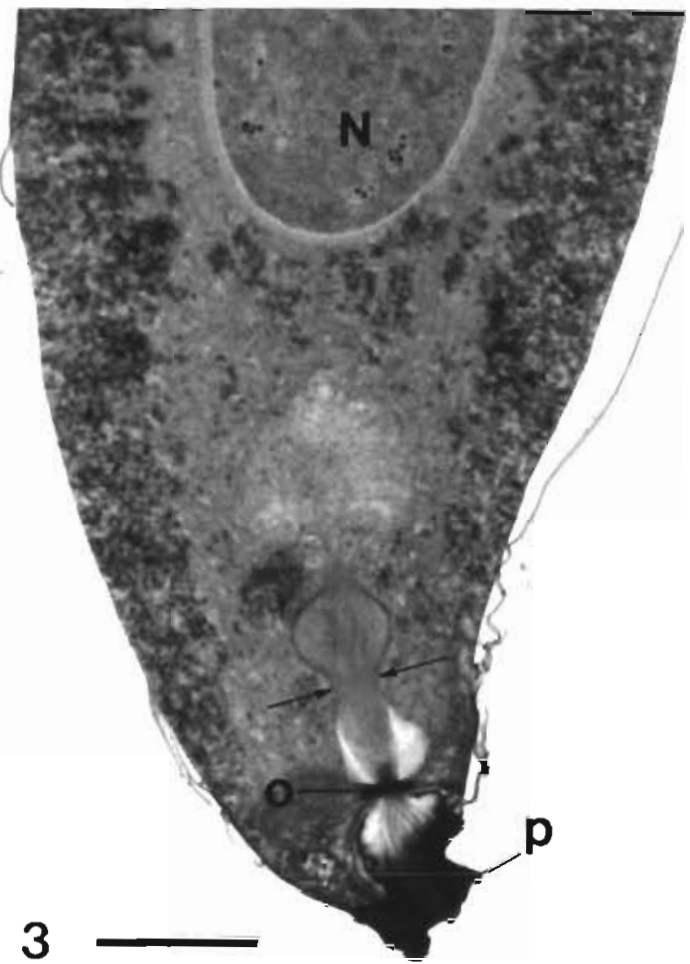

Figs. 1 to 3. Oodinium sp. parasitic on Beroe abyssicola. Fig. 1. B. abyssicola with about 50 visible oodinids (2 indicated by arrowheads). Scale bar $=5 \mathrm{~mm}$. Fig. 2. B. abyssicola. Portion of comb row with 11 oodinids. Scale bar $=500 \mu \mathrm{m}$. Fig. 3 . Oodinium sp. Portion of parasite detached from B. abyssicola. n: nucleus; arrows: transverse constriction that divides peduncular bulb into proximal portion (above! and distal portion (below); 0 : dense ring; : proximal region of peduncle. Scale bar $=25 \mu \mathrm{m}$ 
comb rows, statocyst, and the aboral papillae, together with any attached parasites, from potential harm. All trophozoites on the hydromedusa Euphysa sp. were attached to the subumbrellar surface - on the radial canals or ring canal, on the epithelium between canals, on the manubrium, or on the inner surface of the velum.

\section{Distribution}

Information on the incidence of Oodinium sp. trophozoites in 1989-1990 is summarized in Table 1. (Oodinium jordani was initially seen on Sagitta elegans at Friday Harbor in August 1988.) The oodinid was present on ctenophores as early as December 1987 (recognized later in photographs), but it was late November 1989 before we realized that large numbers of ctenophores were carrying it. Of about 50 Beroe abyssicola examined at that time, most or all were infected. All 10 specimens of the sympatric lobate ctenophore Bolinopsis ?infundibulum collected at the same time were also infected. Oodinium sp. continued to be present in approximately the same abundance through March 1990 and was additionally collected in small numbers on the ctenophores Euplokamis dunlapae, Dryodora glandiformis, and Pleurobrachia bachei, and on the hydromedusa Euphysa sp. in the winter and early spring (the latter was present January to mid-May, but was not examined for parasites until March). During this period, there was no correlation between the size of a host and the number of attached dinoflagellates (e.g. B. abyssicola examined ranged from 8 to $52 \mathrm{~mm}$ in length, yet all sizes appeared to be equally vulnerable as hosts). The number of parasites on each ctenophore varied from one to several hundred. The most densely infected ctenophore was a $25 \mathrm{~mm}$ long B. abyssicola that carried ca 500 oodinids, with one comb row (of which there are 8) bearing ca 100. The greatest number of parasites seen attached to the aboral papillae of $B$. abyssicola was 12 . The trophozoites on a single host varied greatly in size.

Late March-April marked the beginning of the spring zooplankton bloom, in which large numbers of rapidly-growing juvenile ctenophores and medusae appeared. At the same time, incidence of Oodinium sp. decreased markedly, although it continued to occur on the same host species in small numbers through midApril. By late April, Oodinium sp. trophozoites were virtually absent from the hosts and, with a single exception in June, no trophozoites were seen from late April until the last week in October 1990. Oodinium sp. were present in fair numbers on ctenophores by early November, after which extensive freshwater runoff affected surface waters, making ctenophores scarce for the rest of the year.
Trophozoites of Oodinium jordani were seen on Sagitta elegans in 1990 from January through midApril; they were then seen again from mid-May through June 1990 during a period when trophozoites of Oodinium sp. were not seen either on ctenophores or medusae. O. jordani was also seen on $S$. elegans in August 1988 and January and April 1989.

\section{Growth rate of trophozoites}

It was very difficult to follow growth of individual trophozoites for more than $5 \mathrm{~d}$ because, in the laboratory, trophozoites often dropped from their host while still less than $300 \mu \mathrm{m}$ long. It is not known whether this is the result of laboratory conditions and handling, or if it is normal. Based on measurements from more than 25 trophozoites, we believe that it takes ca $20 \mathrm{~d}$ at $10^{\circ} \mathrm{C}$ for a trophozoite of Oodinium sp. living on Beroe abyssicola to grow from first visible size of about $35 \mu \mathrm{m}$ long to the average maximum size of about $350 \mu \mathrm{m}$ in length and $200 \mu \mathrm{m}$ in width. As with all members of the Oodinidae, Oodinium sp. trophozoites do not begin to sporulate until they have dropped from the host.

\section{DISCUSSION}

This is the first instance of parasitism by a dinoflagellate on a member of the phylum Ctenophora (Cachon \& Cachon 1987). It is also the first reported occurrence of an Oodinium on the phylum Cnidaria. [The very dissimilar genus Protoodinium (Family Protoodinidae) is the only other parasitic dinoflagellate described from a medusa - it also occurs on the manubrium, subumbrella, and velum of its host medusae (Cachon \& Cachon 1971, Lauckner 1980).] The present case is particularly unusual since host specificity is common among parasitic dinoflagellates, and the 6 parasitized species reported here represent 4 orders from 2 phyla.

The waters in Friday Harbor are strongly mixed by tidal currents and exhibit little or no vertical stratification. It is questionable whether any of the macroplankton collected in Friday Harbor can be considered resident because of the extreme tidal exchange and water movement. In nearby inlets that are not so strongly mixed, vertical distribution of the plankton is highly stratified, and under these conditions, the hosts of Oodinium sp. do not typically occur in surface waters (Mackie \& Mills 1983, Mackie 1985, Mills unpubl.). Beroe abyssicola usually occurs below $200 \mathrm{~m}$, large Bolinopsis ?infundibulum below $150 \mathrm{~m}$, Euplokamis dunlapae below $100 \mathrm{~m}$, Euphysa sp. below $100 \mathrm{~m}$, and Sagitta elegans below $75 \mathrm{~m}$. Pleurobrachia bachei, a common ctenophore that is rarely infected, usually 
Table 1 Oodinium sp. Incidence of trophozoites on ctenophores and hydromedusae in Friday Harbor, Washington. Hosts are not listed for months in which they were not present

\begin{tabular}{|c|c|c|c|c|c|}
\hline \multirow{2}{*}{$\begin{array}{l}\text { Host species } \\
\text { Date collected }\end{array}$} & \multirow{2}{*}{$\begin{array}{l}\text { No. } \\
\text { collected }\end{array}$} & \multirow{2}{*}{ Infected } & \multicolumn{3}{|c|}{ Oodinium per infected host } \\
\hline & & & $\mathrm{n}$ (host) & Mean & Range \\
\hline \multicolumn{6}{|c|}{ PHYLUM CTENOPHORA } \\
\hline \multicolumn{6}{|c|}{ ORDER BEROIDA } \\
\hline \multicolumn{6}{|c|}{ Family Beroidae } \\
\hline \multicolumn{6}{|c|}{ Beroe abyssicola } \\
\hline Nov 89 & $\sim 50$ & high & $?$ & ? & $?$ \\
\hline Dec 89 & 30 & 97 & 29 & 28 & $2-121$ \\
\hline $\operatorname{Jan} 90$ & 14 & 79 & 11 & 10 & $2-28$ \\
\hline Feb 90 & 27 & 96 & 26 & 13 & $3-47$ \\
\hline Mar 90 & 51 & 82 & 42 & 16 & $1-117$ \\
\hline Apr 90 & 27 & 7 & 2 & 5 & $1-9$ \\
\hline May 90 & 11 & 0 & $\hat{0}$ & $\hat{0}$ & 0 \\
\hline Jun 90 & 58 & 2 & 1 & 2 & 2 \\
\hline Jul 90 & 2 & 0 & 0 & 0 & 0 \\
\hline Oct 90 & 1 & 100 & 1 & 28 & 28 \\
\hline \multicolumn{6}{|c|}{ ORDER LOBATA } \\
\hline \multicolumn{6}{|c|}{ Family Bolinopsidae } \\
\hline \multicolumn{6}{|c|}{ Bolinopsis? infundibulum $\geq 20 \mathrm{~mm}$ long } \\
\hline Nov 89 & 10 & 100 & 10 & $?$ & $?$ \\
\hline Dec 89 & 1 & 100 & 1 & 2 & 2 \\
\hline $\operatorname{Jan} 90$ & 1 & 100 & 1 & 17 & 17 \\
\hline Feb 90 & 2 & 100 & 2 & 8 & $2-15$ \\
\hline Mar 90 & 8 & 37 & 3 & 30 & $1-76$ \\
\hline Apr 90 & 25 & 0 & 0 & 0 & 0 \\
\hline May 90 & 10 & 0 & 0 & 0 & 0 \\
\hline Jun 90 & 7 & 0 & 0 & 0 & 0 \\
\hline Jul 90 & 2 & 0 & 0 & 0 & 0 \\
\hline Aug 90 & 5 & 0 & 0 & 0 & 0 \\
\hline Oct 90 & 6 & 33 & 2 & 8 & $5-12$ \\
\hline Nov 90 & 15 & 67 & 10 & 15 & $1-105$ \\
\hline \multicolumn{6}{|c|}{ Bolinopsis zinfundibulum $<20 \mathrm{~mm}$ long } \\
\hline Mar 90 & 51 & 14 & 7 & 2 & $1-3$ \\
\hline Apr 90 & 79 & 1 & 1 & 1 & 1 \\
\hline May 90 & 15 & 0 & 0 & 0 & 0 \\
\hline Jun 90 & 4 & 0 & 0 & 0 & 0 \\
\hline Aug 90 & 1 & 0 & 0 & 0 & 0 \\
\hline Oct 90 & 4 & 0 & 0 & 0 & 0 \\
\hline Nov 90 & 8 & 63 & 5 & 1 & $1-2$ \\
\hline \multicolumn{6}{|c|}{ ORDER CYDIPPIDA } \\
\hline \multicolumn{6}{|c|}{ Family Euplokamidae } \\
\hline \multicolumn{6}{|c|}{ Euplokamis dunlapae } \\
\hline Feb 90 & 1 & 0 & 0 & 0 & 0 \\
\hline Mar 90 & 6 & 100 & 6 & 4 & $1-9$ \\
\hline Apr 90 & 8 & 0 & 0 & 0 & 0 \\
\hline May 90 & 4 & 0 & 0 & 0 & 0 \\
\hline Jun 90 & 2 & 0 & 0 & 0 & 0 \\
\hline \multirow{2}{*}{\multicolumn{6}{|c|}{$\begin{array}{l}\text { Family Haeckeliidae } \\
\text { Dryodora glandiformis }\end{array}$}} \\
\hline & & & & & \\
\hline $\operatorname{Jan} 90$ & 7 & 14 & 1 & 2 & 2 \\
\hline Feb 90 & 3 & 33 & 1 & 1 & 1 \\
\hline Mar 90 & 10 & 20 & 2 & 3 & $1-5$ \\
\hline Apr 90 & 4 & 0 & 0 & 0 & 0 \\
\hline May 90 & 2 & 0 & 0 & 0 & 0 \\
\hline
\end{tabular}


Table 1 (continued)

\begin{tabular}{|c|c|c|c|c|c|}
\hline \multirow{2}{*}{$\begin{array}{l}\text { Host species } \\
\text { Date collected }\end{array}$} & \multirow{2}{*}{$\begin{array}{c}\text { No. } \\
\text { collected }\end{array}$} & \multirow{2}{*}{$\begin{array}{c}\% \\
\text { Infected }\end{array}$} & \multicolumn{3}{|c|}{ Oodinium per infected host } \\
\hline & & & $\mathrm{n}$ (host) & Mean & Range \\
\hline \multicolumn{6}{|c|}{$\begin{array}{c}\text { Family Pleurobrachiidae } \\
\text { Pleurobrachia bachei }\end{array}$} \\
\hline Feb 90 & 1 & 0 & 0 & 0 & 0 \\
\hline Mar 90 & 109 & 1 & 1 & 1 & 1 \\
\hline Apr 90 & 60 & 0 & 0 & 0 & 0 \\
\hline May 90 & 72 & 0 & 0 & 0 & 0 \\
\hline Jun 90 & 61 & 0 & 0 & 0 & 0 \\
\hline Jul 90 & 26 & 0 & 0 & 0 & 0 \\
\hline Aug 90 & 33 & 0 & 0 & 0 & 0 \\
\hline Sep 90 & 22 & 0 & 0 & 0 & 0 \\
\hline Oct 90 & 7 & 0 & 0 & 0 & 0 \\
\hline Nov 90 & 18 & 0 & 0 & 0 & 0 \\
\hline \multicolumn{6}{|c|}{ PHYLUM CNIDARIA } \\
\hline \multicolumn{6}{|c|}{ ORDER HYDROZOA } \\
\hline \multicolumn{6}{|c|}{ Family Euphysidae } \\
\hline \multicolumn{6}{|c|}{ Euphysa sp. } \\
\hline Mar 90 & 13 & 54 & 7 & 2 & $1-4$ \\
\hline Apr 90 & 38 & 21 & 8 & 2 & $1-4$ \\
\hline May 90 & 5 & 0 & 0 & 0 & 0 \\
\hline Jul 90 & 3 & 0 & 0 & 0 & 0 \\
\hline
\end{tabular}

occurs in the upper $100 \mathrm{~m}$, as do small $B$. ?infundibulum; the vertical distribution of Dryodora glandiformis is not well known, but it also sometimes occurs above $100 \mathrm{~m}$. The vertical distribution of the hosts suggests that the dinospores of Oodinium sp. may typically live deeper than 75 to $100 \mathrm{~m}$ (unless all the hosts acquire the infection near the surface during occasional mixing). The appearance of most of the host species in Friday Harbor varies seasonally, making the life cycle of Oodinium sp. difficult to interpret. Nevertheless, it can be stated that Oodinium sp. trophozoites are numerous in the late fall and winter and then dwindle to zero and are virtually absent from ctenophore and medusan hosts from mid-spring until mid-autumn.

Identification of Bolinopsis ?infundibulum is uncertain because it is not clear to taxonomists which ctenophores correspond to those originally designated as $B$. infundibulum. The animals in question in the San Juan Archipelago are easily identified (Mills 1987); it is only the certainty of their specific name that has not yet been clarified, and a worldwide comparison of members of the genus is required before a definitive name can be applied. The Euphysa sp. that was infected is the deep water morph having jagged, or slightly branched, radial canals; it has been described and figured by Arai \& Mason (1982), and its distribution was discussed by Mackie (1985).

The morphology of the parasite seen on the ctenophores and medusa did not appear to be different from that of Oodinium jordani except with regard to the sharpness of the peduncular ridges. The physical forces affecting $O$. jordani on the fin of a chaetognath, and a parasite on the surface of a cilia-driven ctenophore or the subumbrellar surface of a jet-propulsing medusa, must be quite dissimilar, and may influence the morphology of the peduncle, which is the attachment organelle. Such an environmental effect on morphology is commonly seen among marine invertebrates; e.g. in gastropods (Struhsaker 1968), in barnacles (Darwin 1854, N. D. Pentcheff pers. comm.), and in sponges (Palumbi 1986). We suggest that the noted morphological differences may be a reaction to these forces, and do not necessarily warrant designation of the parasite as a new species. It is evidently a species of the genus Oodinium, and may be a morphological variant of $O$. jordani. (The absence of Oodinium sp. from ctenophore or medusan hosts in May-June 1990 when O.jordani was frequently seen on Sagitta elegans, however, suggests caution in assuming that the 2 forms are identical.)

As with Oodinium jordani on the fins of the chaetognath Sagitta elegans in Friday Harbor and adjacent waters (McLean \& Nielsen 1989), the preferred site of attachment for the ctenophoral and medusan parasite is one in which it is moved about violently by the swimming of the host - by beating of the locomotory cilia in ctenophores and by reciprocal flushing of the bell during swimming pulsations by hydromedusae. McLean \& Galt (1990) have observed similar site selection by a parasitic dinoflagellate (in the genus Apodinium) that occurs on the vigorously beating tail of an appendicularian (larvacean) urochordate at Friday Harbor. 
Although the chaetognath Sagitta elegans can be much more abundant in the San Juan Archipelago and nearby marine waters (known informally as the Salish Sea) than are ctenophores (Mackie \& Mills 1983, Mackie 1985, Mills unpubl.), we suggest that ctenophores are at least equally important as hosts for oodinids. Beroe abyssicola and Bolinopsis? infundibulum showed a very high incidence of infection in the winter (most carried trophozoites) in contrast to $S$. elegans (most were not infected); most of these ctenophores carried numerous trophozoites, whereas infected $S$. elegans typically bore 1 or 2, with rarely as many as 14 .

Since the oodinids are large among the Protista and are readily visible with the unaided eye, and since the surface plankton has been studied intensively at Friday Ilarbor iñ lecent years, we feel that such parasites would have been recognized previously had they been present. It is of interest that this report of ectoparasitism in the Ctenophora and Cnidaria, the former a phylum not previously known to be parasitized by the Dinoflagellata (Cachon \& Cachon 1987), cites 6 infected genera in 2 phyla; and that Oodinium jordani, which was described quite recently, was reported from a member of yet another phylum. If, indeed, Oodinium sp. proves to be identical to $O$. jordani, it is possible that this species is a recent arrival in the waters of the San Juan Archipelago, and that it is rapidly becoming compatible with a plethora of hosts representing at least 3 phyla.

Acknowledgements. We are grateful to Dr Dennis Willows, Director of the Friday Harbor Laboratories, University of Washington, for use of research facilities. Special thanks are extended to our many colleagues who helped collect ctenophores. The described parasitic phenomenon on ctenophores was first seen during joint observations by $\mathrm{Dr}$

Responsible Subject Editor: A. K. Sparks, Seattle, Washington, USA
Larry Madin, Dr Eugene Kozloff and C.E.M. Mr Urs SchmidtOtt drew our attention to the parasite on Euphysa.

\section{LITERATURE CITED}

Arai, M. N., Mason, J. C. (1982). Spring and summer abundance and vertical distribution of hydromedusae of the central Strait of Georgia, British Columbia. Syesis 15: 7-15

Cachon, J., Cachon, M. (1971), Protoodinium chattoni Hovasse. Manifestations ultrastructurales des rapports entre le péridinien et la méduse-hôte: fixation, phagocytose. Arch. Protistenk. 113: 293-305

Cachon, J., Cachon, M. (1987). Parasitic dinoflagellates. In: Tayior, F. J. R. (ed.) The biology of dinoflagellates. Blackwell Scientific Publications, Oxford, p. 571-610

Darwin, C. (1854). A monograph on the subclass Cirripedia with figures of all the species. Ray Society, London

Lauckner, G. (1980). Diseases of Cnidaria. In: Kinne, O. (ed.) Diseases of marine animals, Vol. I. John Wiley \& Sons, Chichester, p. 167-237

Mackie, G. O. (1985). Midwater macroplankton of British Columbia studied by submersible PISCES IV. J. plankton Res. 7: 753-777

Mackie, G. O., Mills, C. E. (1983). Use of the Pisces IV submersible for zooplankton studies in coastal waters of British Columbia. Can. J. Fish. Aquat. Sci. 40: 763-776

McLean, N., Galt, C. P. (1990). Apodinium floodi n. sp., a dinoflagellate (Dinoflagellata: Apodinidae) ectoparasitic on Oikopleura labradoriensis (Urochordata: Larvacea). Dis. aquat. Org. 9: 213-219

MicLean, N., Nielsen, C. (1989). Oodinium jordani n. sp., a dinoflagellate (Dinoflagellata: Oodinidae) ectoparasitic on Sagitta elegans (Chaetognatha). Dis aquat. Org. 7: 61-66

Mills, C. E. (1987). Phylum Ctenophora. In: Kozloft, E. N. (ed.) Marine invertebrates of the Pacific Northwest. University of Washington Press, Seattle and London, p. 79-81

Palumbi, S. R. (1986). How body plans Limit acclimation: responses of a demosponge to wave force. Ecology 67: 208-214

Struhsaker, J.W (1968). Selection mechanisms associated with intraspecific shell variation in Littorina picta (Prosobranchia: Mesogastropoda). Evolution 22: 459-480

Manuscript first received: June 13, 1990

Revised version accepted: February 20, 1991 